\title{
The Local Politics of Decentralized Environmental Policy in Guatemala
}

\section{By: CLARK C. GIBSON and FABRICE E. LEHOUCQ}

Gibson, Clark C. and Fabrice E. Lehoucq. "The Local Politics of Decentralized Environmental Policy in Guatemala," Journal of Environment and Development, Vol. 12, No. 1 (March 2003): 28-49.

Made available courtesy of SAGE PUBLICATIONS LTD: http://jed.sagepub.com/

\section{***Note: Figures may be missing from this format of the document}

\begin{abstract}
:
This article identifies the conditions leading to successful decentralized environmental management in the developing world. It focuses on Guatemala, a country where lawmakers have devolved forest protection to 331 municipalities. This study is based on an original survey of 100 randomly chosen mayors who held office between 1996 and 2000 and a database constructed from several national censuses that include geographic, demographic, socioeconomic, and biophysical variables. It suggests that local community pressure and central government support encourage mayors to value forest protection. Survey results also indicate that mayors allocate staff to forest protection when the central government makes this a priority. Mayors also dedicate personnel to this sector when they have more education and when their municipalities boast larger amounts of forested area.

Keywords: environmental management; decentralization; incentives; forestry; municipal government; Guatemala

\section{Article:}

Two powerful ideas have jointly produced a new form of public policy in many developing countries. One, environmentalism, is at the core of postmaterialist issues. The other, decentralization, is at the core of the new federalism and appears in a variety of new center-local governmental partnerships around the world. Policy makers, donors, and scholars long frustrated by the lackluster performance of national governments now increasingly advocate the marriage of environmentalism and decentralization.
\end{abstract}

According to proponents of decentralization, making lower-level officials responsible for the provision of a wide variety of goods and services should result in more efficient and participatory government. Unlike national-level agencies, the argument goes, local politicians and officials will design more appropriate policies because they are more familiar with their environments and users' needs. Hoping to harness local knowledge for better environmental protection, environmentalists have sought to make municipal governments responsible for protecting environmental resources. Forests are one of the principle targets of their efforts (Food and Agriculture Organization of the United Nations, 1999).

Critics, however, argue that decentralizing forest protection will lead to even greater levels of deforestation. They claim that local governments will underinvest in environmental protection because they cannot capture all the benefits of the public goods the environment creates (Bahl, 
1999; Manor, 1999). Decentralizing forestry policy, they argue, may undermine the pursuit of the public goods of biodiversity and global and regional climate stability. Shifting responsibility for forest protection to lower levels of government may also endanger the flora and fauna that furnish products central to the livelihoods of millions of rural people (Arnold, 1990,1992; Costanza et al., 1997; Gibson, McKean, \& Ostrom, 2000; Ostrom, 1990).

In this study, we examine the political realities of decentralized environmental policy at the municipal level in Guatemala. Although traditionally centralized and authoritarian, Guatemala's 1985 constitution called for transferring $8 \%$ of the national budget (increased to 10\% in 1994) to the country's 331 municipalities. Ten years later, politicians promulgated a new forestry law that made municipalities responsible for monitoring compliance with the new law, which included a ban on felling trees without a government permit. These policy innovations take on increased importance as forests declined from 65\% of Guatemala's territory in 1950 to $34 \%$ in 1996 (Dix, 1999).

We explore the local politics of decentralized forestry in this article by asking two questions: (a) What drives mayors to invest municipal resources to manage forests, and (b) is the management of forests significantly different to mayors than other sectors in their municipality? We test hypotheses generated from these questions and their related literatures using two sets of data: an original survey of 100 randomly chosen mayors (out of 331 mayors) who held office from 1996 to 2000 and a database constructed from several national censuses that include geographic, demographic, socioeconomic, and biophysical variables. Figure 1 includes a map of Guatemala and of our 100 surveyed municipalities.

We find that local organizations and central government support help explain mayoral attitudes and behaviors regarding decentralized forest policy. Only these political economic variables significantly drive mayoral attitudes toward forest management. Mayors' personal characteristics (often part of postmaterialist analyses) and the environmental characteristics of their municipalities (often part of macroeconomic analyses) help explain why mayors hire staff to monitor forest conditions. We also find mayors putting relatively less importance on forestry issues than on other development issues. These results demonstrate that environmental policy is both similar and different than other issues. It is similar because mayors will care about forests when it is in their political interest to do so. It is different because it may take relatively more outside funding and local-level pressure in forestry than in other sectors to induce mayoral action.

\section{FIGURE IS OMITTED FROM THIS FORMATTED DOCUMENT}

This article consists of six parts. In the first, we discuss decentralization theory and its relationship to forestry policy. In the second, we present the Guatemalan context in general and explain why mayors might care about the forests. We flesh out a model of mayors and forestry in the third section and include hypotheses about the role of personal, municipal, and political economic variables; we test these hypotheses in the fourth section. Given our findings that mayors do not invest great efforts to manage forests, we discuss forestry in comparison to other municipal sectors in the fifth section. In the final section we discuss some of the broader implications of this study. 


\section{Decentralization in Theory and Practice}

We define decentralization as any act in which a central government formally cedes power to actors and institutions at lower levels in a political- administrative and territorial hierarchy (Agrawal \& Ribot, 1999; Mahwood,1983; Rondinelli,1990; Smoke, 1993). Whether presented as formal political structures or the informal rules of rural communities, decentralization's positive effects are lauded in scores of books and articles. Such work is also consonant with the current development thinking of donors and multilateral lending agencies (e.g., InterAmerican Development Bank, 1994; Organization for Economic Cooperation and Development, 1997; World Bank, 1988,1997) that now fund numerous projects with decentralized components. The World Bank, for example, recently identified 60 countries where decentralization is an important component of development strategy (Bahl, 1999).

The purported benefits of decentralization are legion. Decentralization can lead to the more efficient delivery of public services (e.g., Edel \& Rothenberg, 1972; Oates, 1972; Rivlin, 1992; World Bank, 1988), more equitable outcomes (e.g., Feldstein, 1975; Maro, 1990), and greater citizen participation in public affairs (Dahl, 1981; De Tocqueville, 1835/ 1945). Similarly, others argue that decentralization increases the flexibility of government policies (e.g., Bish \& Ostrom, 1973), fuels local institutional capacity (e.g., Rondinelli, McCullough, \& Johnson, 1989), and maximizes the accountability of government (e.g., Blair, 2000; Crook \& Manor, 1998; Dahl, 1981). Indeed, some authors hardly distinguish between decentralization and democracy at all (e.g., Blair, 1998; Totemeyer, 1994).

The evolution of policies concerning forest management reflects this conceptual change in the conventional wisdom about the proper locus of governance. Forest policy has undergone pronounced change over the past 50 years (Arnold, 1992, 1998). Until and through the 1960s, forest policy had been oriented toward the commercial aspects of forest management. Central governments or private interests managed forests. The stock and flow of forests managed for the market would ensure its preservation. If the land underneath the trees was considered more valuable than the wood, governments generally did not stand in the way of forest clearing (Richards \& Tucker, 1988). This orientation also found its way into overseas aid programs: Industrialized countries promoted the scientific, professional management of forest resources to meet economic goals of the governments of less developed countries; vast timber plantations were the prescription of the day.

The failure of most of the plantation projects and increasing understanding about the ecologically valuable role that forests played led to a shift in forest policies. In the late 1970s, international donors began to sponsor forest projects that included the participation of local people as a core part of a global strategy of slowing down rates of deforestation. Ideally, policy makers began to include locals in all phases of project design, with the technical help of professional foresters. In many countries, the rise of community forestry coincided with efforts-domestic or external in origin - to decentralize and downsize governments. Dozens of countries founded communitybased programs of forest management, such as the Joint Forest Management Program in India, the Leasehold Forestry Program in Nepal, the Guesselbodi Project in Niger, the Turkana Rural Development Project in Kenya, and the Bay Region project in Somalia. Because local communities live with forests, are primary users of forest products, and create rules that 
significantly affect forest condition, their inclusion in forestry management schemes is now considered essential by many researchers and policy makers (e.g., Arnold, 1992).

Both the concepts and implemented programs of decentralized forestry policy generally fail to acknowledge that the success of decentralization hinges on the behavior of the local politician. Although conceding that it will take significant "political will" to create a successful decentralized policy, most studies of decentralization assume munificent local governments interested in maximizing social welfare. Local- level officials are also assumed to embrace any new powers coming from the center. They are presumed to want to comply with the new decentralized reforms and only fall short because of a lack of technical competence or appropriate financial resources.

Yet there are good reasons to believe that the reality of local-level politics diverges from this idealized version of decentralization. Similar to their national-level counterparts, local politicians worry about staying in power in addition to - and in some cases to the exclusion of - reaping the efficiency and democratic benefits of decentralization (Gibson, 1999). Staying in power in turn means that local politicians must make choices about how to employ their limited time and resources to serve political as well as programmatic goals. Recent research on the politics of decentralization finds that the timing, structure, and success of decentralized reforms are contingent on the incentives faced by constitutional, electoral, and party systems. These incentives in turn affect the choices of presidents, legislators, and party officials (Ames \& Keck, 1997-1998; O’Neill, 1999; Willis, Garman, \& Haggard, 1999). Indeed, Richard Crook and James Manor (1998), in a study of eight rural districts in Bangladesh, India, Ivory Coast, and Ghana, found that the localities with the best provision of public services are those with mayors independently elected of the municipal council and where council members are elected from geographically separate districts within the municipality. Similarly, Fiszbein's (1997) study of 16 Colombian municipalities found that citizen satisfaction and local governmental performance is a function of electoral competition, community involvement, and innovative leadership.

What is important about these analyses is that they unpack "political will": They allow the central actors in policies of decentralization to hold explicitly political preferences that can and do overwhelm the dictates of economic efficiency. Given that local politicians are usually the individuals charged with carrying out decentralized policies, we argue that explaining the success or failure of such policies demands an understanding of the incentives and constraints local politicians face. We outline the general incentives that Guatemalan mayors face in the next section.

\section{Decentralization and Forests in Guatemala}

Guatemala remains one of the poorest societies and most ethnically complex countries in Latin America, even if multilateral agencies classify it as a midlevel developing country. In 1998,31\% of the adult population was illiterate. Life expectancy was 67 years in 1997 . The 1998 gross domestic product (GDP) per capita remains low, about \$3,505 (PPP). The U.N. Development Program (2000) gave Guatemala a human development index of 0.619 in 1998 — placing it 120th among the 174 countries of the world (Sistema de Naciones Unidas en Guatemala, 1999). Approximately one half of the roughly 12 million people who live in Guatemala (whose territory consists of 108,890 km2) are indigenous - individuals who speak one of two dozen Mayan 
languages, dress in indigenous garb, or otherwise identify themselves as indigenous. As of 2000, one half of the population lives in the rural areas of 331 municipalities.

Guatemala hardly seems like terrain appropriate for decentralization or environmental protection. Until the 1980s, the military appointed mayors in many municipalities, although many municipal boards still became the fulcrum of local politics. As part of its overall strategy of retreating from formal control of the state, the Guatemala military convened elections for a Constituent Assembly that promulgated a new constitution in 1985 (Jonas, 2000; Torres-Rivas \& Aguilera,1998). A key plank in the new constitution was a provision that $8 \%$ of the national budget be transferred to municipalities. A successful referendum on a host of constitutional changes in 1994 included a provision that increased the monies earmarked for municipalities to $10 \%$ of the national budget. Since 1985 , voters have elected mayors in 4 -year intervals. The candidate with the plurality of votes becomes mayor; seats on the municipal councils are allocated according to proportional representation.

It was in three of the poorest Latin American countries that lawmakers developed the most innovative forestry programs in the 1980s and 1990s. Similar to Bolivia and Honduras, policy makers in Guatemala decided to delegate major responsibilities and, more important, substantial funds to municipal governments. In 1994, Bolivian politicians enacted a Popular Participation Law that transformed provincial sections into municipalities that for the first time allowed citizens to elect their mayors and council officials (O’Neill, 1999). In 1996, Bolivian and Guatemalan policy makers enacted new forestry laws that devolved significant authority and financial incentives to municipalities to administer public forests within their jurisdictions (Pacheco \& Kaimowitz,1998). Although municipal government has a long history in both Guatemala and Honduras, it was only in the 1990s that central governments devolved important environmental responsibilities to local governments (Gálvez Borrell \& Camposeco Hurtado, 1997; Godichet, del Cid, \& Trputec, 1997).

The 1996 Guatemalan Forestry Law devolves two important responsibilities to municipalities. First, Article 58 states that municipalities will execute the systems of supervision (vigilancia) that are required to prevent the illegal exploitation of forest products at the level of each municipality with the help of the National Forestry Institute (INAB) and will support the latter's activities. In the control of the authorized exploitation of forest products, INAB will send copies of the licenses and management plans to the respective municipalities. Article 54 notes that municipalities can grant licenses to fell trees within the urban perimeter for volumes of less than 10 cubic meters per farm and by year. For greater volumes, INAB must grant the license. Second, under Article 71, the state will grant incentives through INAB in coordination with the Ministry of Public Finances to landowners, including municipalities, that dedicate themselves to projects of reforestation and maintenance on lands appropriate for forestry empty of forests, along with the management of natural forests, and social groups with legal standing that as a result of a legal arrangement occupy municipal property.

Our interviews with INAB and other officials indicate that both provisions may very well be examples of central governments shifting responsibility over problematic policy domains to lower-level public officials. In the last two decades of the 20th century, the Guatemalan state went bankrupt and underwent a rather dramatic downsizing. Indeed, one of the lowest rates of 
effective taxation makes the Guatemala state one of the poorest in the developing world, with no more than $10 \%$ of the GDP ending up in government coffers. In a revenue-poor context, it is not surprising that central state politicians turned over key components of environmental protection to municipalities, especially when international donors are touting the virtues of community management and decentralization.

Of the mayors surveyed, $71 \%$ told us that forest management was at least the same if not more important than other activities during their term in office. Our survey also shows that mayors generally report that forests are important for their different uses. Of those surveyed, 59\% say that timber is as or more important than other land uses, $30 \%$ for forests used as pastures (cattle and horses often forage in forested areas), and $64 \%$ for forests as reserves. And although only $40 \%$ of mayors report that they think citizens find timber at least as or more important than other sectors, this may reflect that most citizens' interactions with forests do not concern timbering per se but instead using forests for daily livelihood inputs.

Mayors also report — and official estimates support - that there are substantial amounts of forest in Guatemala. Measuring forest extent is difficult because definitions about what constitutes a forest vary considerably. About $20 \%$ of the surveyed mayors thought that their municipality had at least $10 \%$ forest cover. Using estimates compiled by researchers at Del Valle University, Guatemala City (see Appendix on the construction of the forest cover variable), forest cover is wide ranging in our sample of 100 municipalities. Whereas the average municipality has nearly 10,000 hectares of forest cover according to these estimates, the standard deviation is nearly 40,000 hectares. The majority of municipalities have less than $10 \%$ forest cover; $29 \%$ have greater than $21 \%$ cover. These data are likely to undercount forested land vis-à-vis the mayors: Mayors will encounter woodlots and small forest stands that are not usually counted in official forest cover estimates. And although there are few grounds on which a comparison of mayoral and foresters' cover figures is useful, given their different definitions and viewpoints, there is one intriguing similarity: We find that $27 \%$ of mayors responded that their total forest cover was greater than $21 \%$; the Del Valle data show $29 \%$ of municipalities with forest cover of greater than $21 \%$.

\section{Hypotheses}

We argue that local politicians are the key to explaining compliance with forest protection legislation. No matter how well designed the technical aspects of decentralized policy may be, local-level politicians will influence which policies receive attention and which ones languish. We hypothesize that mayors will be more likely to comply with the decentralized forest policy if first, community organizations and nongovernmental organizations (NGOs) organized around forestry issues exist in the municipality, and second, the central government assigns personnel and budgetary resources to the municipality to help manage forests.

Similar to many parts of the world, rural people in Guatemala live in communities possessing forest commons. People in many of these communities are also heavily organized: They have committees that protect and monitor forest boundaries and conditions (e.g., Becker \& León, 2000; Elías, 1998; Gibson, 2001; Gibson, Lehoucq, \& Williams, 2001; ReynaContreras, Elías, Cigarroa, \& Moreno, 1998; Tucker, 1999). Many communities therefore have social capital, the network of norms and rules that generate trust necessary to solve the collective action problems 
that common pool resources generate. Elinor Ostrom (1990), in particular, argued that relatively small groups dependent on forest resources possessing well-defined boundaries often have positive effects on forest conditions.

There are two ways in which social capital can increase the municipality's commitment to forest protection. First, as the number and density of community organizations in their municipality increases, mayors will carry out environmental legislation because it will be relatively costless for them to do so. Assigning resources to protect forests - a common pool resource that by definition is hard to monitor-will be rational because official efforts will have a multiplicative effect with social capital. Second, to the extent that forest-oriented community organizations and NGOs exist, the mayor will face community pressure to help protect forests.

Mayors may also comply with conservation policies if the central government facilitates their implementation. By reducing the costs of implementing the decentralized policy, the central government may overcome the negative incentives the environmental protection often generates for local politicians. Such central government actions as periodic visits by forestry officials, training of local municipal employees, transfer of funds for forest management, and other types of support for a local government's efforts to monitor forests should encourage mayors to follow legal statutes.

There are other ways to explain the behavior of mayors. Specialists in environmental politics have furnished several reasons why the forest might be important to mayors. Most of the theory and systematic data regarding preferences about the environment come from the experience of industrialized countries (Rohrschneider \& Dalton, 2002). Scholars generally argue that the more affluent and educated members of society are, the more environmentally aware and active they will be. Theories that buttress such arguments come from modernization and political culture perspectives. With modernization come the increased levels of citizen education, dense communication structures, social mobility, and affluence that facilitate political action. These trends are also thought to combine with a new political culture of postmaterialism that places emphasis on values such as the environment and participation (Inglehart, 1989).

We include several control variables in our models, as mayoral action depends in part on the context in which forests actually exist. It stands to reason that wealthier municipalities will do a better job of protecting their forests, either because municipal revenues are greater or because the municipality itself is wealthier. Similarly, the more forest cover a municipality possesses, the more likely it is that the mayor will develop programs to monitor forest conditions. Finally, some argue that indigenous peoples might be kinder to the environment because they have acquired the knowledge necessary to take care of natural resources (Elías, 1998). This variable will serve as a control on our measure of social capital; it measures whether local networks have an independent effect on the dependent variables.

We measure compliance with forest legislation behaviorally. One way is by asking mayors to rank their policy priorities on a scale of 1 to 5 . A second way is to ask mayors to identify the number of municipal employees dedicated to forest protection and then ask them to estimate the total number of municipal employees. By dividing the former by the latter, we came up with a variable that measures their commitment to forest protection in light of their policy concerns. 
Given that detailed budgetary data at the municipality level does not exist in Guatemala, our measure of central government funding is from our survey, which we assessed through a question that asks how frequently the central government gave significant funds to the municipality for forest management. Our number of the community organizations and NGOs also stems from the survey, when we asked the mayors to estimate these numbers. To assess the effect of postindustrial factors, we rely on survey questions that ask mayors about the number of years of schooling they have and their placement on a 1 to 10 ideological scale (where 1 is the extreme left and 10 is the extreme right). Except for forest cover, our control variables stem from the 1994 population census. The census has standard questions about the demography of each municipality (population, ethnic groups, etc.) and about development (number of households with plumbing and electricity, income per capita, etc.).

\section{Models and Results}

We present two logistic regression models and their estimations in Table 2 (the source and measurement of all variables are listed in the Appendix). Descriptive statistics for the variables employed is presented in Table 1. Models 1 and 2 include independent variables that reflect a mayor's personal characteristics, municipality characteristics, and political economy variables (central government funding, number of local organizations related to forestry, and importance of timber revenue). Model 1 uses a dependent variable measuring a mayor's assertion of the importance of forest monitoring during his or her 1996-2000 mayoral term. Because 62 of the sampled municipalities have no forest employees, Model 2 uses an ordinal dependent variable representing the percentage of municipal employees engaged in forest monitoring: $0=$ no municipal forest employees, $1=1 \%$ to $9 \%$ of municipal employees are forest related, $2=$ more than $10 \%$ of municipal employees are forest related.

Table 1

Descriptive Statistics for Variables in Regression Models

\begin{tabular}{|c|c|c|c|c|c|}
\hline Variable & $\mathrm{N}$ & Minimum & Maximum & Mean & $\begin{array}{l}\text { Standard } \\
\text { Deviation }\end{array}$ \\
\hline Education (years) & 99 & 0 & 18 & 10.16 & 4.77 \\
\hline Forest as priority ( 1 to 5 ) & 100 & 1 & 5 & 3.25 & 1.3 \\
\hline Timber revenues ( 1 to 5 ) & 100 & 1 & 5 & 1.97 & 1.05 \\
\hline Forest employees (0 to 2 ) & 98 & 0 & 2 & 0.5 & 0.62 \\
\hline Mayor left or right & 100 & 0 & 10 & 3.45 & 2.71 \\
\hline \multicolumn{6}{|l|}{ Indigenous } \\
\hline population (\%) & 99 & 0.59 & 98.6 & 49.32 & 36.91 \\
\hline \multicolumn{6}{|l|}{ Per capita income } \\
\hline (1,000 quetzales) & 92 & 0 & 1.22 & 0.26 & 0.22 \\
\hline Forestry organizations & 100 & 0 & 75 & 5.8 & 12.27 \\
\hline Development level & 99 & 23.18 & 256.44 & 135.4 & 59.4 \\
\hline \multicolumn{6}{|l|}{ Forest cover } \\
\hline (1,000 hectares) & 100 & 0 & 3,285 & 96.7 & 398.7 \\
\hline
\end{tabular}

Note: See appendix for precise definitions and measures. 
Table 2

Logistic Regression Estimates for Predictors of Mayoral Attitude and Action

\begin{tabular}{|c|c|c|}
\hline & $\begin{array}{l}\text { Forest } \\
\text { as Priority } \\
\text { (1) }\end{array}$ & $\begin{array}{c}\text { Municipal } \\
\text { Forest Employees } \\
\text { (2) }\end{array}$ \\
\hline \multicolumn{3}{|l|}{ Personal characteristics } \\
\hline Education & $.039(0.043)$ & $.114^{*}(0.058)$ \\
\hline Political ideology & $-.098 \quad(0.075)$ & $.003(0.1)$ \\
\hline \multicolumn{3}{|l|}{ Municipality characteristics } \\
\hline Municipal income & $-.103(0.926)$ & (1.2) \\
\hline Municipal development & $\begin{array}{ll}0 & (0.004)\end{array}$ & $.002(0.005)$ \\
\hline Indigenous population & $.002(0.006)$ & $-.008(0.007)$ \\
\hline Forest cover & $(0.001)$ & $.003^{*}(0.001)$ \\
\hline \multicolumn{3}{|l|}{ Political economy factors } \\
\hline Funding for forestry & $.346 *(0.144)$ & $.507^{* *}(0.183)$ \\
\hline Forestry organizations & $.037 *(0.020)$ & $.03 \quad(0.021)$ \\
\hline Timber receipts & $.210(0.297)$ & $.4 \quad(0.255)$ \\
\hline Pseudo $R^{2}$ & .21 & .45 \\
\hline$N$ & 100 & 100 \\
\hline
\end{tabular}

Note: All models use logit estimators. Coefficients are unstandardized betas; standard errors are in parentheses.

${ }^{*} p=.05,{ }^{* *} p=.01$.

Table 3

Probability Estimates From Equations 1 and 2 (in percentages)

\begin{tabular}{|c|c|c|c|c|c|c|c|c|}
\hline & & & \multicolumn{2}{|c|}{ Funding for Forestry } & \multicolumn{4}{|c|}{ Forestry Organizations } \\
\hline & \multicolumn{2}{|c|}{ Mean } & $5 \%$ & $95 \%$ & & $5 \%$ & & $95 \%$ \\
\hline \multicolumn{9}{|l|}{ Forest as priority } \\
\hline 1. Much less & \multicolumn{2}{|c|}{11.3} & 16.0 & 3.9 & & 13.3 & & 5.4 \\
\hline 2. Less & \multicolumn{2}{|c|}{17.7} & 21.9 & 7.3 & & 19.7 & & 9.7 \\
\hline 3. Same & \multicolumn{2}{|c|}{28.9} & 29.3 & 17.4 & & 29.4 & & 21.1 \\
\hline 4. More & \multicolumn{2}{|c|}{24.9} & 20.3 & 27.5 & & 22.7 & & 28.7 \\
\hline \multirow[t]{3}{*}{ 5. Much more } & \multicolumn{2}{|c|}{17.3} & 12.5 & 43.9 & & 14.9 & & 35.2 \\
\hline & \multirow[b]{2}{*}{ Mean } & \multicolumn{4}{|c|}{$\begin{array}{l}\text { Funding } \\
\text { for Forestry }\end{array}$} & \multicolumn{3}{|c|}{ Forest Cover } \\
\hline & & $5 \%$ & $95 \%$ & $5 \%$ & $95 \%$ & & $5 \%$ & $95 \%$ \\
\hline \multicolumn{9}{|l|}{$\begin{array}{l}\text { Percentage forest } \\
\text { employees }\end{array}$} \\
\hline $0 \%$ & 57.2 & 74.6 & 38.9 & 70.3 & 17.8 & & 63.4 & 51.4 \\
\hline $1 \%$ to $9 \%$ & 40.7 & 24.3 & 56.7 & 28.5 & 69.3 & & 34.9 & 46.0 \\
\hline $10 \%+$ & 2.1 & 1.0 & 4.3 & 1.2 & 12.8 & & 1.6 & 2.6 \\
\hline
\end{tabular}

Note: Estimates from results in Table 1. Change in probability indicates moving variable to stated percentile and holding all other variables at their means.

Equation 1 demonstrates that two out of three political economic variables - central government funding and the number of forest organizations - have a significant effect on a mayor's attitudes about the importance of forests. Neither municipal nor personal characteristics are statistically significant. But two municipal and personal characteristics emerge as important in explaining the percentage of forest employees in a municipality (Equation 2): the number of years a mayor has spent in school and the amount of forest cover in a municipality. Funding for forestry also 
remains significant, whereas the number of forestry organizations becomes less important in this model $(\mathrm{p}=.16)$.

Converting the results of the ordered logistic models into conditional probabilities allows a more detailed look at the influence of the significant variables. In Table 3 we can see that as forest funding from the central government increases, the probability increases that a mayor will claim forests as a policy priority. For example, although the probability that a mayor answered that forests were much less important than other sectors during his term was $11 \%$, the shift due to forestry funds (from $5 \%$ to $95 \%$ of mean) gives the probability range from $16 \%$ to $3.9 \%$. The mean probability that a mayor claimed that forestry was much more important is $17.3 \%$. When shifting the funding variable to $95 \%$ of mean, the probability increases to nearly $44 \%$.

Local forestry organizations also affect a mayor's priorities, although less dramatically. A shift from $5 \%$ to $95 \%$ of the mean number of forest organizations reduces the probability that a mayor will claim forestry as much less important from $13.5 \%$ to $5.4 \%$. And the same shift in means for forestry organizations more than doubles the probability from $14.9 \%$ to $35.2 \%$ that a mayor will claim forestry is more important than other sectors.

The bottom half of Table 3 reveals the change in probabilities for Equation 2, which uses the share of municipal employees monitoring forests as its dependent variable. Although the mean probability that mayors employed no one in the forest management is $57.2 \%$, this level drops to about $39 \%$ if education is moved to $95 \%$ of its mean. And mayors are 4 times more likely to have more than $10 \%$ of their employees in forest management if they are highly educated (from $1 \%$ to $4.3 \%$ ). Forest cover produces more modest changes in the number of forest employees, for example, from $5 \%$ to $95 \%$ of mean forest cover reduces a mayor's probability of having no staff in forest management only by $12 \%$. But central government funding generates the most spectacular changes: A mayor is 4 times less likely to have no forestry employees if they are at $95 \%$ of mean for funding, and they are 10 times more likely to have more than $10 \%$ of their municipal staff in forestry at high levels of funding.

\section{Forests and Mayors' Priorities}

Our results suggest that mayors treat forests in response to a political calculus. They ranked forestry as a policy priority and invested staff in forest monitoring where the central government has made this a priority and where forestry community organizations exist. Not surprisingly, the probability that mayors allocated personnel to forestry issues also increased as their municipality became forested. As more than half of the municipalities had "no" forests, most of the sampled mayors did nothing about forest monitoring precisely because no one encouraged them to take care of a resource that their jurisdictions do not possess. The probability that mayors spent money on forests also increased as they became more educated. Our general findings underscore the importance of political factors in administrative decentralization: Similar to any other policy issue, mayors will take steps to protect forests when it is in their political interest to do so.

But the forest management is also unlike other sectors to the mayors. Forest monitoring has by far the lowest rankings when looking at mayors' first and second priorities. Only 1\% ranked it as one their two top priorities. The other goods of modernization, such as water, education, 


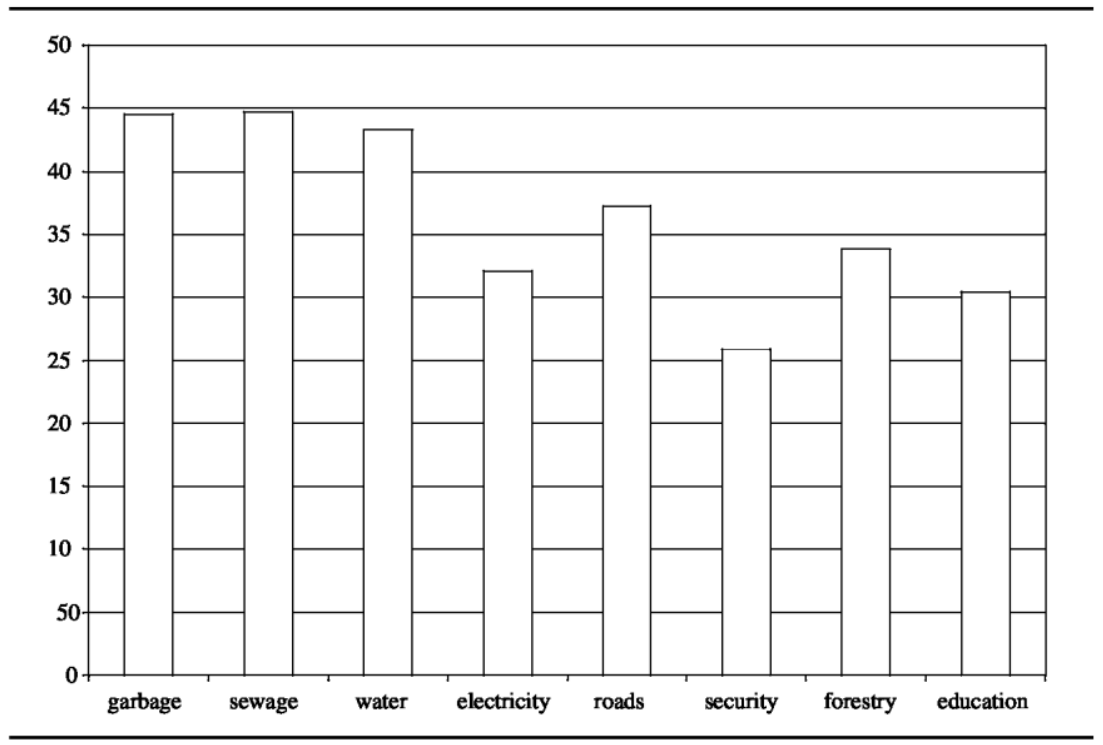

Figure 2: Mayors' Interest in Decentralization

Note: Column values are a summation of mayoral responses to what they consider the most appropriate balance of municipal vs. center control ( 1 = least municipal control, 2 = most municipal control).

and electrification, were far higher on the mayors' agendas. Sixty-three of the mayors ranked water as their first or second priority. Forty-six ranked education as their first or second priorities. Between $17 \%$ and $19 \%$ of the mayors ranked electrification, health, roads and transportation, or sewage disposal as a top-two concern. Even when allowed to rank all sectors simultaneously, for example, when allowed the chance for "cheap talk," we still find noticeably less enthusiasm for forest management.

Finally, Figure 2 presents data from a series of speculative questions that we asked mayors about the appropriate balance of center/municipal control. We added the values of all respondents; the scale ranged from $1=$ little municipal control/very high central government control to $5=$ very high municipal control/little central government control. Thus, if every mayor thought that the municipality should fully control a given sector, this sector would score 500 on this scale. Forests rank fifth out of eight categories - not the worst but hardly a ringing endorsement of any view that would have mayors desiring greater control over the forests. Much of this lukewarm response, we believe, can be traced back to the few benefits that local-level politicians receive from forest management: Why control something with so little pay-off?

\section{Conclusions}

This study examines the incentives mayors face to protect the environment. We explore the reasons why local politicians monitor forest conditions in Guatemala, a country that devolved key environmental responsibilities to each of its 331 municipalities. Similar to much of the developing world, Guatemala is an economically poor country with a record of less than spectacular governmental performance. Understanding when and why mayors comply with environmental obligations is important for identifying the conditions under which decentralizing 
control over common pool resources works or not in countries whose forests and other environmental resources are under threat.

The evidence suggests that environmental issues such as forest preservation do not hold special rank in the eyes of Guatemalan mayors. Indeed, $99 \%$ of our survey respondents did not rank forestry monitoring as a Number 1 or 2 priority. In part, this result is a product of the fact that most municipalities have less than $10 \%$ forest cover and therefore need not worry about taking care of this resource. This response also reflects the difficulty of meeting the goal in question: Forest resources can be quintessential common pool resources - difficult to exclude people from their use while rivalrous in consumption.

We hypothesize that as an elected official, a mayor will invest in forest monitoring if it has a political pay-off. We operationalized our argument in models that tested the effects of forestry community organization and central government influence. In the model of mayoral priorities, only these two factors were statistically significant. Neither the mayor's education nor ideology shaped his or her decision to favor forest monitoring; nor did municipal levels of development, existing forest cover, or timber receipts impact on his or her decision to do anything about forests. The conclusion is that local community pressure and central government support for forestry will make forests a priority for the mayor.

In the model using a more stringent measure of commitment to forestry-share of municipal employees dedicated to monitoring forests - only central government support for forests remains statistically significant. That the number of local organizations does not lead to more municipal staff monitoring forests makes sense because the organizations probably are monitoring the forests themselves. Mayors therefore believe forest monitoring is important when local community groups and central government encourage them to make this a priority. They only allocate staff to monitor forests, however, when the central government helps them meet this objective. Mayors also dedicate personnel to protecting forests if large collections of trees exist in their jurisdictions. Municipalities with more educated mayors also promote this objective.

For those who wish to protect forests, the study provides both a caveat and some hope. The warning is that, unsurprisingly, mayors appear to be moved by political economic incentives. This means that decentralized programs must do far more than transfer unfunded responsibilities to the municipal level. This may be a sure way of realizing the fears of economists and conservationists about the underinvestment in environmental conservation at the local level. On the other hand, funding and local pressure does seem to work: Mayors are not obstinately refusing to manage forests. At certain levels of both of those factors, decentralized environmental policy may indeed produce desirable outcomes at the aggregate level.

\section{Acknowledgements}

We thank David García and his team for their fieldwork in Guatemala as well as Carew Boulding and Lilian Márquez for their database management skills. Edwin Castellanos and his team at the Centro de Estudios Ambientales of the Universidad del Valle de Guatemala provided the data regarding forest resources. Emily Beaulieu, Nicole Carter, Russ Dalton, and three anonymous reviewers offered valuable comments on earlier drafts. Barak Hoffman assisted with statistical 
procedures. We also thank the National Science Foundation (SBR-9521918) for the financial support that made this research possible. We thank David L. Wall (Department of Geography, St. Cloud State University) for allowing us to use the database of census returns he developed with Lehoucq.

\section{Appendix}

Variable Sources and Measurement

\begin{tabular}{|c|c|c|}
\hline Variable Name & Source & Question (If Applicable) \\
\hline \multicolumn{3}{|c|}{ Regression models, descriptive statistics, and probability estimates for Tables 1,2 , and 3 in text } \\
\hline Education & Survey & $\begin{array}{l}\text { How many years of school have you completed? (divided by } 100 \text { for } \\
\text { regression analysis) }\end{array}$ \\
\hline Political ideology & Survey & $\begin{array}{l}\text { Place yourself along a } 10 \text {-point scale from } 1 \text { to } 10 \text { on a political spectrum, } \\
1 \text { being extreme left and } 10 \text { being extreme right. (divided by } 100 \text { for } \\
\text { regression analysis) }\end{array}$ \\
\hline Municipal income & $\begin{array}{l}1994 \text { census/1997 Fundación } \\
\text { Centroamericana de } \\
\text { Desarrollo \& Instituto de } \\
\text { Fomento Municipal report }\end{array}$ & $\begin{array}{l}\text { Calculated by dividing total municipal income by total population from } \\
\text { the } 1994 \text { census (divided by } 1,000 \text { for regression analysis; results in } 1,000 \mathrm{~s} \\
\text { of quetzales) }\end{array}$ \\
\hline $\begin{array}{l}\text { Municipal } \\
\text { development }\end{array}$ & 1994 census & $\begin{array}{l}\text { Calculated by adding variables of percentage of dwellings with electricity, } \\
\text { sewage systems, and water }\end{array}$ \\
\hline $\begin{array}{l}\text { Indigenous } \\
\text { population }\end{array}$ & 1994 census & $\begin{array}{l}\text { Percentage of municipal population speaking an indigenous language } \\
\text { (divided by } 100 \text { for regression analysis) }\end{array}$ \\
\hline Forest cover & University del Valle & $\begin{array}{l}\text { Laboratorio de SIG y Sensores Remotos, University del Valle de Guatemala } \\
\text { using } 1999 \text { National Forestry Institute data (divided by } 10,000,000 \text { for } \\
\text { regression analysis; results in 1,000s of hectares) }\end{array}$ \\
\hline $\begin{array}{l}\text { Funding for } \\
\text { forestry }\end{array}$ & Survey & $\begin{array}{l}\text { How frequently does the government give significant amounts of funds for } \\
\text { forestry }(1=\text { least, } 5=\text { most }) \text { ? }\end{array}$ \\
\hline $\begin{array}{l}\text { Forestry } \\
\text { organizations }\end{array}$ & Survey & $\begin{array}{l}\text { Sum of answers to: How many nongovernmental organizations work in your } \\
\text { municipality? How many community organizations work in the forestry } \\
\text { sector in your municipality? }\end{array}$ \\
\hline
\end{tabular}




$\begin{array}{ll}\begin{array}{l}\text { Timber receipts } \\ \begin{array}{l}\text { Municipal forest } \\ \text { employees }\end{array}\end{array} & \text { Survey } \\ \begin{array}{l}\text { Forest monitoring } \\ \text { versus other } \\ \text { mayoral activities }\end{array} & \text { Survey } \\ \end{array}$

Mayors' Interest in Decentralization (Figure 2 in Text)
Water $\quad$ Survey

Education Survey

Electrification Survey

Health Survey

Roads and Survey

transportation
How important were timber revenues to your municipality's budget $(1=$ least, 5 = most $)$ ?

Percentage calculated by dividing the answers to: How many municipal employees work in the forestry sector? How many municipal employees are there in the total? (divided into three categories per text)

Please rank the importance of forest monitoring versus other mayoral activities (1 = least, 5 = most).

In your opinion, what is the right balance of control between municipal government and central government regarding (sector name)? ( 1 = little municipal government, 5 = high municipal government)

In your opinion, what is the right balance of control between municipal government and central government regarding (sector name)?

( 1 = little municipal government, 5 = high municipal government)

In your opinion, what is the right balance of control between municipal government and central government regarding (sector name)?

( 1 = little municipal government, 5 = high municipal government)

In your opinion, what is the right balance of control between municipal government and central government regarding (sector name)? ( 1 = little municipal government, 5 = high municipal government)

In your opinion, what is the right balance of control between municipal government and central government regarding (sector name)?

( 1 = little municipal government, 5 = high municipal government)

\section{Appendix (continued)}

\begin{tabular}{|c|c|c|}
\hline Variable Name & Source & Question (If Applicable) \\
\hline Sewage disposal & Survey & $\begin{array}{l}\text { In your opinion, what is the right balance of control between municipal } \\
\text { government and central government regarding (sector name)? } \\
\text { ( } 1=\text { little municipal government, } 5 \text { = high municipal government) }\end{array}$ \\
\hline Trash removal & Survey & $\begin{array}{l}\text { In your opinion, what is the right balance of control between municipal } \\
\text { government and central government regarding (sector name)? } \\
\text { (1= little municipal government, } 5 \text { = high municipal government) }\end{array}$ \\
\hline Forest monitoring & Survey & $\begin{array}{l}\text { In your opinion, what is the right balance of control between municipal } \\
\text { government and central government regarding (sector name)? } \\
\text { (1= little municipal government, } 5=\text { high municipal government) }\end{array}$ \\
\hline
\end{tabular}

\section{References}

Agrawal, A., \& Ribot, J. (1999). Accountability in decentralization: A framework with

South Asian and West African cases. Journal of Developing Areas, 33, 473-502.

Ames, B., \& Keck, M. (1997-1998). The politics of sustainable development: Environmental policy making in four Brazilian states. Journal ofInteramerican Studies \&WorldAffairs,39, 4. Arnold, J. (1990). Socialforestry and communal management in India (Social Forestry Network Paper 11b). London: Overseas Development Institute.

Arnold, J. (1992). Communityforestry: Ten years in review. Rome: Food and Agriculture Organization of the United Nations.

Arnold, J. (1998). Managingforests as common property. Rome: Food and Agriculture Organization of the United Nations.

Bahl, R. (1999). Fiscal decentralization as development policy. Public Budgeting and Finance, $19,59-75$. 
Becker, C., \& Leon, R. (2000). Indigenous forest management in the Bolivian Amazon: Lessons from the Yuracare People. In C. Gibson, M. McKean, \& E. Ostrom (Eds.), People and forests: Communities, institutions, and governance (pp. 163-192). Cambridge, MA: MIT Press.

Bish, R., \& Ostrom, V. (1973). Understanding urban government. Washington, DC: American Enterprise Institute for Public Policy Research.

Blair, H. (1998). Spreading power to the periphery: An assessment of democratic local governance

(Program and Operations Assessment Report No. 21). Washington, DC: USAID.

Blair, H. (2000). Participation and accountability at the periphery: Democratic local governance in six countries. World Development, 28, 21-39.

Costanza, R., d'Arge, R., de Groot, R., Farber, S., Grasso, M., Hannon, B., et al. (1997). The value of the world's ecosystem services and natural capital. Nature, 387, 253-260.

Crook, R., \& Manor, J. (1998). Democracy and decentralisation in South Asia and West Africa. Cambridge, UK: Cambridge University Press.

Dahl, R. (1981). The city in the future of democracy. In L. D. Feldman (Ed.), Politics and government of urban Canada (pp. 47-49). New York: Methuen.

De Tocqueville, A. (1945). Democracy in America. New York: Vintage. (Original work published 1835)

Dix, A. (1999). Balance de los recursos naturales [Balance sheet of natural resources]. In E. Torres-Rivas \& J. A. Fuentes (Eds.), Guatemala: Las particularidades del desarrollo humano (Vol. II, pp. 311-356). Guatemala City, Guatemala: United Nations-European Union.

Edel, M., \& Rothenberg, J. (Eds.). (1972). Readings in urban economics. New York: Macmillan. Elías, S. (1998). Autogestión comunitaria de recursos naturales: Estudio de daso en

Totonicapán

[Community self-management of natural resources: The case of Tononicapán]. Guatemala: FLACSO.

Feldstein, M. (1975). Wealth neutrality and local choice in public education. American Economic Review, 65, 75-89.

Fiszbein, A. (1997). The emergence of local capacity: Lessons from Colombia. World Development, 25, 1029-1043.

Food and Agriculture Organization of the United Nations. (1999). State ofthe world'sforests.

Rome: Author.

Fundación Centroamericana de Desarrollo \& Instituto de Fomento Municipal. (1999). La estructura del presupuesto municipal de los municipios de Guatemala: Año de 1997 [The structure of the municipal budget of Guatemalan muncipalities: 1997]. Guatemala City, Guatemala: Author.

Gálvez Borrell, V., \& Camposeco Hurtado, R. (1997). Guatemala: Politicas de descentralización y capacidades de gestión administrativa y financiera de las municipalidades [Guatemala:

Decentralization policies and municipal administrative and financial capacity]. Guatemala, City, Guatemala: FLACSO.

Gibson, C. (1999). Politicians and poachers: The political economy of wildlife policy in Africa. Cambridge, UK: Cambridge University Press.

Gibson, C. (2001). Forest resources: Institutions for local governance in Guatemala. In J. Burger, E. Ostrom, R. Norgaard, D. Policansky, \& B. Goldstein (Eds.), Protecting the commons: A framework for resource management in the Americas (pp. 46-71). Washington, DC: Island Press. 
Gibson, C., Lehoucq, F., \& Williams, J. T. (2001). Does tenure matter to resource management? Property rights and forests in Guatemala. Social Science Quarterly, 83, 206-225.

Gibson, C., McKean, M., \& Ostrom, E. (Eds.). (2000). People andforests: Communities, institutions, and governance. Cambridge, MA: MIT Press.

Godichet, O., del Cid, J., \& Trputec, Z. (1997). Descentralización ygobierno municipal en Honduras [Decentralization and municipal government in Honduras]. San Salvador: FLACSO-El Salvador.

Inglehart, R. (1989). Culture shift in advanced industrial countries. Princeton, NJ: Princeton University Press.

InterAmerican Development Bank. (1994). Fiscal decentralization: The search for equity and efficiency. In Economic and social progress in Latin America: 1994 report (pp. 175-234). Washington, DC: Author.

Jonas, S. (2000). Of centaurs and doves: Guatemala's peace process. Boulder, CO: Westview. Mahwood, P. (1983). Local government in the Third World. Chichester, UK: Wiley. Manor, J. (1999). The political economy of democratic decentralization. Washington, DC: World Bank.

Maro, P. (1990). The impact of decentralization on spatial equity and rural development in Tanzania. World Development, 18, 673-693.

Oates, W. (1972). The political economy offiscalfederalism. Lexington, MA: Lexington Books. O’Neill, K. (1999). Decentralization in the Andes. Unpublished doctoral dissertation, Harvard University.

Organization for Economic Cooperation and Development. (1997). Final report of the DAC Ad Hoc Working Group on participatory development and good governance, Parts I and II. Paris: Author.

Ostrom, E. (1990). Governing the commons: The evolution of institutions for collective action. Cambridge, UK: Cambridge University Press.

Pacheco, P., \& Kaimowitz, D. (1998). Introducción [Introduction]. In P. Pacheco \& D. Kaimowitz (Eds.), Municipios ygestiónforestal en el trópico Boliviano (pp. 5-23). La Paz, Bolivia: CIFOR, CEDLA, \& TIERRA.

Reyna Contreras, V., Elías, S., Cigarroa, C., \& Moreno, P. (1998). Comunidades rurales y areas protegidas: Análisis de la gestión colectiva en dos sitios de El Petén [Rural communities and protected areas: Analysis of collective management in two sites in Petén]. Guatemala City, Guatemala: FLACSO.

Richards, J. F., \& Tucker, R. P. (1988). World deforestation in the twentieth century. Durham, NC: Duke University Press.

Rivlin, A. (1992). Revising the American dream. Washington, DC: Brookings Institution.

Rohrschneider, R., \& Dalton, R. J. (2002). A global network? Transnational cooperation among environmental groups. Journal of Politics, 64, 510-533.

Rondinelli, D. (1990). Decentralization, territorial power, and the state: Acritical response. Development and Change, 21, 491-500.

Rondinelli, D., McCullough, J., \& Johnson, R. (1989). Analyzing decentralization policies in developing countries: Apolitical-economy framework. Development and Change, 20,57-87. Sistema de Naciones Unidas en Guatemala. (1999). Guatemala: El rostro rural del desarrollo humano, edición 1999 [Guatemala: The rural face of human development, 1999 edition]. Guatemala City, Guatemala: Author. 
Smoke, P. (1993). Local government fiscal reform in developing countries: Lessons from Kenya. World Development, 21, 901-902.

Torres-Rivas, E., \& Aguilera, G. (1998). Del autoritarismo a la Paz [From authoritarianism to peace]. Guatemala City, Guatemala: FLACSO.

Totemeyer, G. (1994). Challenges for democracy, decentralization, and empowerment in Africa. Regional Development Dialogue, 15, 49-61.

Tucker, C. (1999). Manejo forestal y políticas nacionales en La Campa, Honduras [Forest management and national politics in La Campa, Honduras]. Mesoamérica, 3, 111-134.

Willis, E., Garman, C., \& Haggard, S. (1999). The politics of decentralization in Latin America. Latin American Research Review, 34, 7-56.

World Bank. (1988). The world development report 1988. New York: Oxford University Press. World Bank. (1997). The world development report 1997: The state in a changing world. New York: Oxford University Press. 